\title{
Humoral immunity to influenza in an at-risk population and severe influenza cases in Russia in 2016-2017
}

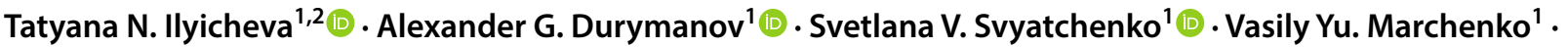 \\ Ivan A. Sobolev ${ }^{3}$ (1) Anastasiya Yu. Bakulina ${ }^{1,2}$ - . Natalia I. Goncharova ${ }^{1} \cdot$ Natalia P. Kolosova $^{1} \cdot$ Ivan M. Susloparov $^{1}$. \\ Olga G. Pyankova ${ }^{1}$ (D) Alexander B. Ryzhikov ${ }^{1} \cdot$ Rinat A. Maksyutov $^{1}$ (D)
}

Received: 3 March 2018 / Accepted: 19 April 2018 / Published online: 5 June 2018

(c) Springer-Verlag GmbH Austria, part of Springer Nature 2018

\begin{abstract}
This work aimed to analyze the herd immunity to influenza among a Russian population living in regions with an increased risk of emergence of viruses with pandemic potential, and to isolate and investigate virus strains from severe influenza cases, including fatal cases, during the 2016-2017 epidemic season. In November 2016 - March 2017 highly pathogenic influenza outbreaks were registered in Russia among wild birds and poultry. No cases of human infection were registered. Analysis of 760 sera from people who had contact with infected or perished birds revealed the presence of antibodies to A(H5N1) virus of clade 2.3.2.1c and A(H5N8) virus of clade 2.3.4.4. The 2016-2017 influenza epidemic season in Russia began in weeks 46-47 of 2016 with predominant circulation of influenza A(H3N2) viruses. Strains isolated from severe influenza cases mainly belonged to 3C.2a.2 and 3C.2a.3 genetic groups. Up to the 8th week of 2017 severe influenza cases were often caused by influenza B viruses which belonged to $1 \mathrm{~A}$ genetic group with antigenic properties similar to B/Brisbane/60/2008. All influenza A and B virus strains isolated in the 2016-2017 epidemic season were sensitive to oseltamivir and zanamivir.
\end{abstract}

\section{Introduction}

Influenza is a human respiratory disease, which causes annual influenza outbreaks, and in some cases pandemics. Seasonal influenza epidemics often begin with increased morbidity in children, achieve peak within 2-6 weeks and last from 8 to 12 weeks. Usually influenza epidemics with a predominant $\mathrm{H} 3 \mathrm{~N} 2$ subtype are accompanied by high morbidity and mortality [1].

Handling Editor: Ayato Takada.

Electronic supplementary material The online version of this article (https://doi.org/10.1007/s00705-018-3904-9) contains supplementary material, which is available to authorized users.

Tatyana N. Ilyicheva

ilyichev@mail.ru

1 Vector State Research Centre of Virology and Biotechnology, Koltsovo, Novosibirsk Region 630559, Russia

2 Novosibirsk State University, Novosibirsk 630090, Russia

3 Scientific Research Institute of Experimental and Clinical Medicine, Novosibirsk 630060, Russia
In Russia in 2016-2017 an increase in influenza morbidity was registered in weeks $46-47$ of 2016. At the start of the epidemic, influenza $\mathrm{A}(\mathrm{H} 3 \mathrm{~N} 2)$ virus was mainly predominant, and the peak of morbidity was registered in the 2nd week of 2017. Later on (from the 3rd to 7th week of 2017) the number of infected people remained at its maximum level. In this period, the predominant influenza agent changed: up to the 7th week of 2017 influenza A(H3N2) had prevailed, after the 8 th week influenza $B$ virus was predominant [2]. Generally, the main features of the 2016-2017 epidemic season included earlier and longer increases in morbidity as compared to previous seasons, less intensity in the epidemic process and lower fatality. About 55.9 million people were vaccinated just before the epidemic season resulting in an enhanced herd immunity to influenza in the Russian population [3].

Since influenza viruses permanently circulate in the wild, predominantly among wild birds, there is a continuous possibility of the emergence of pandemic virus strains. Influenza viruses have segmented genomes represented by single-stranded RNA of negative polarity. When two virus particles, which belong to different influenza A subtypes, enter one target cell, virus variants with unpredicted antigenic and virulent features can emerge due to reassortment. 
The most dangerous situation can take place if influenza epidemics in the human population is concurrently accompanied by severe highly pathogenic avian influenza outbreaks at the same location.

To track the possible emergence of highly pathogenic influenza virus or its markers in the human population, we regularly test human blood samples and analyze influenza virus strains from severe cases giving special attention to fatal cases [4]. Our research team collects blood sera from humans living in Russian regions located in zones containing migratory pathways for waterfowl since these locations have an increased risk for the emergence of viruses with pandemic potential. We analyze all sera to detect the presence of antibodies to highly pathogenic influenza viruses. In addition, we detect antibody titers to vaccine strains to test herd immunity to seasonal influenza. From November 2016 to March 2017 we registered several avian highly pathogenic influenza outbreaks caused by $\mathrm{A}(\mathrm{H} 5 \mathrm{~N} 8)$ virus of clade 2.3.4.4 in central parts of Russia [5]. We studied nasopharyngeal swabs and paired blood sera in all people who had contact with infected or perished birds.

This paper aims to analyze the herd immunity to influenza among a Russian population living in regions with an increased risk of emergence of viruses with pandemic potential, as well as among humans who had contact with infected or perished birds during the outbreaks of highly pathogenic influenza in January-March 2017 in the European part of Russia. It also describes the isolation and investigation of virus strains from severe human influenza cases, including fatal infections, during the 2016-2017 epidemic season.

\section{Materials and methods}

Work with autopsy materials and blood sera were approved by the Ethics Committee IRB 00001360 affiliated with SRC VB Vector (No.2 d.d. Protocol, 20 May 2008). Blood sera were collected from humans living in zones with waterfowl migratory pathways. Analysis of the herd immunity to influenza was carried out using the results obtained in hemagglutination inhibition (HI) tests as described previously [6]. A/California/07/09(H1N1)pdm09, A/Hong Kong/4801/2014 (H3N2) and B/Brisbane/60/2008 (Victoria lineage) influenza viruses were kindly provided by the WHO Collaborating Centre in Atlanta, the United States. The WHO Collaborating Centre in Beijing, China, kindly furnished A/Anhui/01/2013(H7N9) virus. A/great crested grebe/Tyva/34/2016 (HPAI H5N8) virus (clade 2.3.4.4.) was isolated by the authors in 2016 in South Siberia [7]. Sera were analyzed in microneutralization assays, as described in [8].

Autopsy material (fragments of bronchi, trachea and lungs) from people who presumably died from influenza as well as clinical material (nasopharyngeal swabs in transport medium) from people with severe ARVI and patients vaccinated against influenza before the epidemic were provided by the Russian regional laboratories. According to our regional virological laboratories' PCR analysis data, all samples were positive for the presence of influenza virus RNA. At Vector State Research Centre of Virology and Biotechnology (SRC VB Vector) the samples were studied by PCR again, and then all materials regardless of PCR data were used for virus isolation in MDCK cell culture (London line) by infecting cell monolayers, as described previously [4].

We typed/subtyped isolated influenza virus strains and studied their antigenic features in $\mathrm{HI}$ tests according to WHO recommendations [9] using post-infectious ferret reference sera. HI test results were confirmed by real-time PCR data, as described previously [4]. When testing sensitivity to oseltamivir and zanamivir, we used a fluorescent method according to the WHO-recommended protocol [10].

Sequencing was carried out at the SRC VB Vector Common Use Centre, Koltsovo. To determine the nucleotide sequences of viral genes, viral RNA was isolated using RIBO-sorb RNA/DNA Extraction Kit (InterLabService, Moscow, Russia) according to the manufacturer's instruction. Reverse transcription reactions were carried out with the Uni12 primer for influenza A and the Uni11 primer for influenza B viruses using a First Strand cDNA Synthesis Kit (Thermo Scientific, Lithuania) according to the manufacturer's instruction. The products of amplification were isolated using a QIAquick gel extraction kit (QIAGEN, USA). Sanger sequencing was performed on 3500xL Genetic Analyzer (24-capillary) (Applied Biosystems, USA). The nucleotide sequences were studied using Vector NTI Advance 10 program package (Invitrogen, Carlsbad). Deep sequencing of amplicons covering complete genomes was performed on an Illumina MiSeq using MiSeq reagent kit v3. (Illumina, San Diego, USA).

\section{Results}

\section{Investigation of herd immunity}

To study the herd immunity, we tested 4979 human blood sera collected in October-November 2016 from humans living in territories with a high risk of emergence of influenza viruses with pandemic potential (Fig. 1). None of the samples reacted with highly pathogenic influenza A(H5N8) and $\mathrm{A}(\mathrm{H} 7 \mathrm{~N} 9)$ viruses in $\mathrm{HI}$ tests, even at 1:20 dilution. Figure 2 depicts the results obtained in the HI tests with vaccine strains.

When comparing the results obtained in autumn 2016 with the previous season, we noted that the number of positive sera to influenza viruses $\mathrm{A}(\mathrm{H} 1 \mathrm{~N} 1)$ pdm09 increased by 


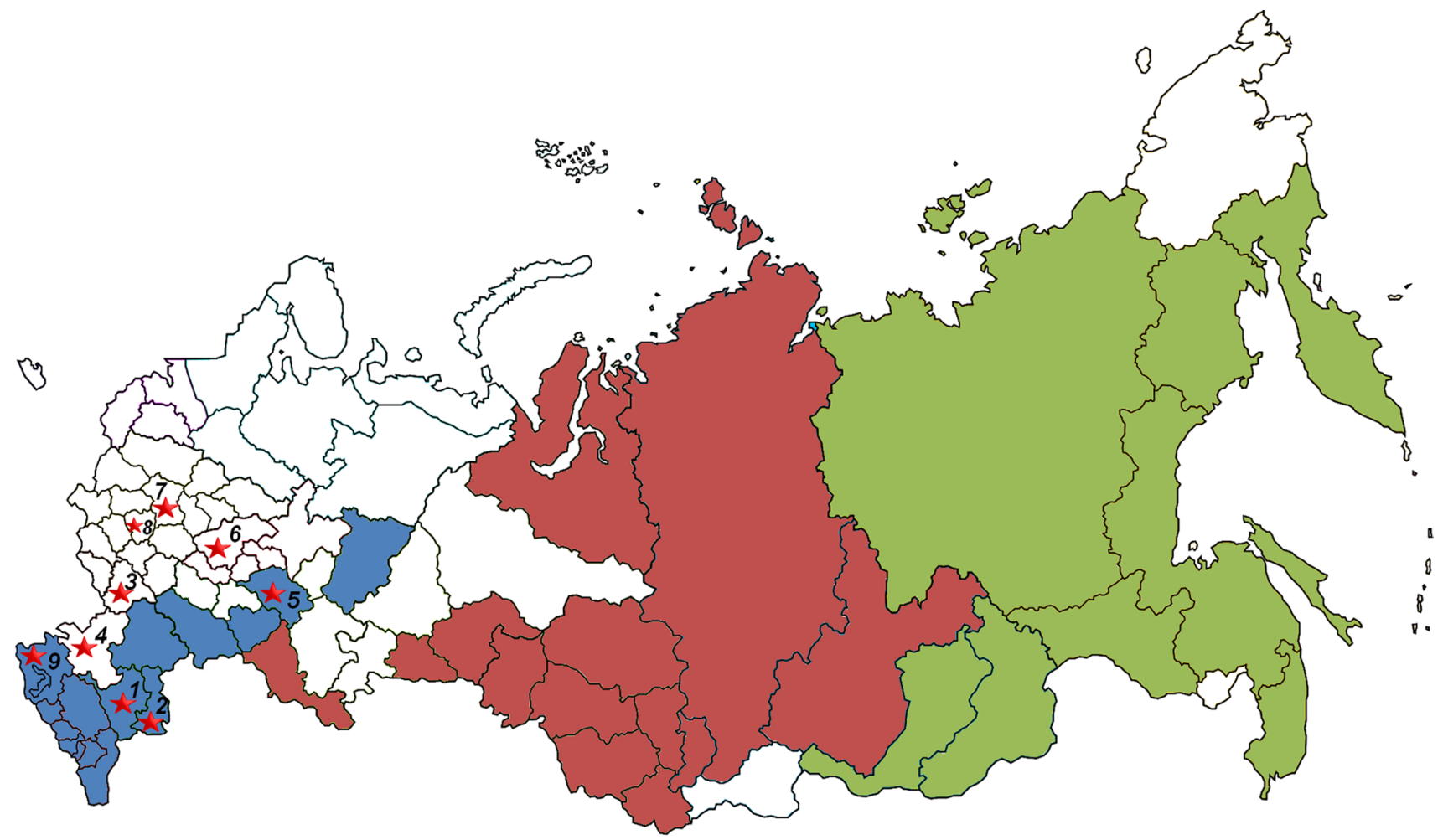

Fig. 1 Russian regions with high risk of emergence of influenza viruses of pandemic potential. Blue, European part of Russia; Red, Ural and Western Siberia; Green, Eastern Siberia and Russian Far East. 1-9, outbreaks of highly pathogenic influenza among wild birds and poultry: 1, Republic of Kalmykia; 2, Astrakhan region; 3, Voronezh region; 4, Rostov region; 5, Republic of Tatarstan; 6, Nizhniy Novgorod region; 7, Moscow region; 8, Tula region; 9, Krasnodar Krai (color figure online)
Fig. 2 Seropositivity in the studied groups (\%). Blue, European part of Russia; Red, Ural and Western Siberia; Green, Eastern Siberia and Russian Far East (color figure online)

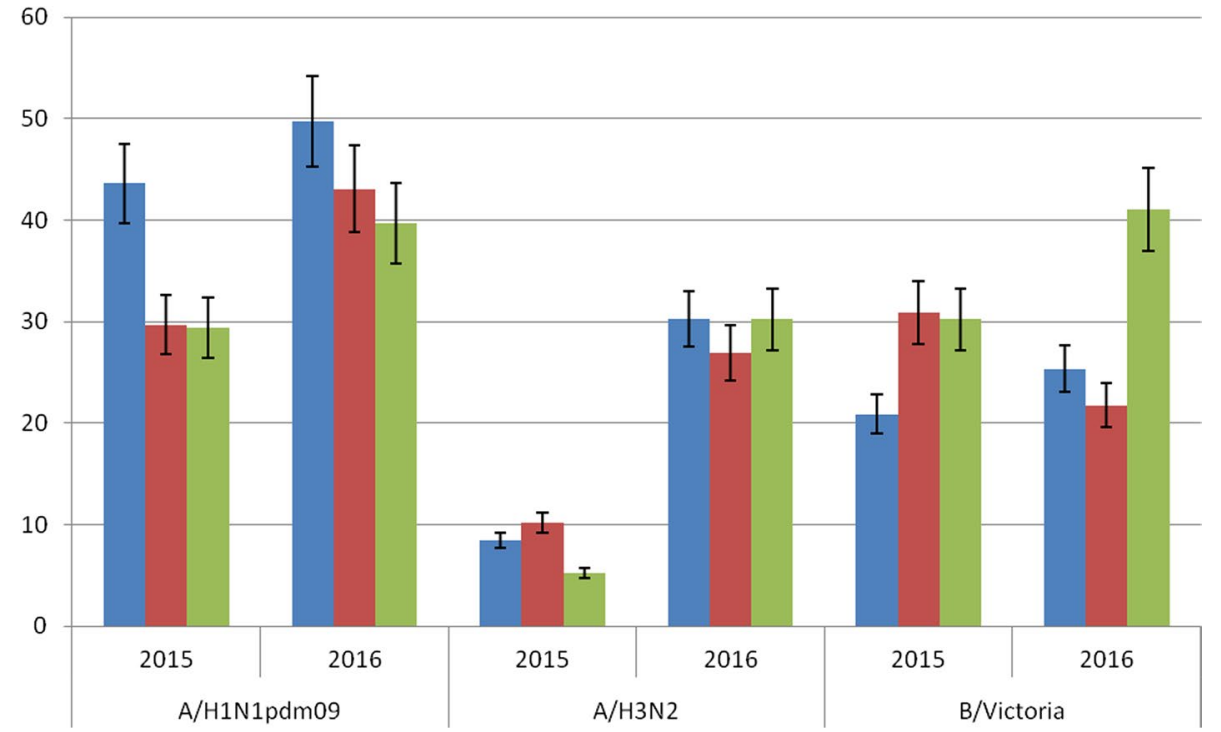

$7-14 \%$ in all regions. We can explain this phenomenon both by vaccination and human illness during the 2015-2016 epidemics when influenza A(H1N1)pdm09 dominated in Russia [4]. Positive sera to influenza $\mathrm{A}(\mathrm{H} 3 \mathrm{~N} 2)$ virus increased by $17-27 \%$. This fact is undoubtedly explained by mass vaccination of the population in September-October 2016 since during the 2015-2016 epidemic only several confirmed influenza $\mathrm{A}(\mathrm{H} 3 \mathrm{~N} 2)$ cases were registered. The level of herd immunity to influenza $B$ virus remained the same, i.e. $20-30 \%$ of sera interacted with $B /$ Brisbane/60/2008 
(Victoria lineage) in the HI test. The Russian Far East was the only exception with the level of positive sera to influenza B increasing from 30 to $44 \%$.

In 2015-2016 the vaccine included the virus B/ Phuket/3073/2013 (Yamagata); thus, we carried out seromonitoring for that virus, and strains isolated in that season predominantly belonged to the Yamagata lineage. In the 2016-2017 season, the vaccine included the virus B/ Brisbane/60/2008 (Victoria); consequently, we tested sera against that virus. It is believed that vaccination in Ural and Western Siberia failed to provide sufficient levels of antibodies against B/Brisbane/60/2008 (Victoria) in human sera.

During the epidemic season, November 2016-March 2017, in Russia (Fig. 1) several outbreaks of highly pathogenic influenza among wild birds and poultry were registered [5]. There was no illness among humans. We analysed 760 nasopharyngeal swabs from all personnel that had contact with infected or perished birds. Only two samples were positive in the PCR analysis for the presence of influenza virus RNA and two A/H5N8 influenza viruses were isolated in eggs (A/unknown/Tatarstan/86/2017 epi_isl_275433; A/ unknown/Tatarstan/94/2017 epi_isl_275432). However, there was no clinical evidence of infection in patients, and paired blood sera samples taken at 21-day intervals were negative in $\mathrm{HI}$ test and neutralization reaction.

During the outbreaks and 3 weeks after clean-up operations, we collected sera from people who had contact with infected or perished birds. Sera were analyzed in HI tests with actual antigens from highly pathogenic influenza virus as well as horse erythrocytes.

Previously we showed that $\mathrm{H} 5$ antigens of different clades can fail to interact in HIs test with heterological sera [7]. This is a significant challenge, since one should check which strains are used for seromonitoring. To analyze sera from people participating in clean-up operations after highly pathogenic outbreaks, we selected antigens that reacted in $\mathrm{HI}$ tests with sera from recovering ferrets infected with influenza A/H5 virus strains, viruses which caused outbreaks in Russia in 2005-2017. Table 1 demonstrates the inverse values of these sera titers observed in the HI test.

As Table 1 shows, antibodies to all circulating subclades of highly pathogenic A/H5 viruses were detected with viruses A/rook/Chany/32/2015 (H5N1) and A/chicken/Sergiyev Posad/38/2017 (H5N8) in the HI test. Therefore, we studied all sera from people who had contact with infected or perished birds using the HI test and both antigens.

Out of 760 tested paired sera, antibodies to A/rook/ Chany/32/2015 (H5N1) were detected in 28 paired samples, whereas antibodies to (H5N8) virus A/chicken/Sergiyev Posad/38/2017 were found in 60 paired samples. Only in one case antibodies were absent in the first serum (HI titer $>20$ ) however these registered 3 weeks after the outbreak had begun (HI titer $=80$ ). Table 2 demonstrates the study results for sera from people who had contact with infected or perished birds during the outbreak caused by highly pathogenic influenza.

Sera positive in HI tests were analyzed in neutralization reactions. Only about $40 \%$ of samples positive in the HI test were also positive in the neutralization reaction. Nevertheless, all paired sera except for one led to the same results: either both sera were positive or both of them were negative.

\section{Characterization of influenza viruses isolated from autopsy and clinical material}

From October 2016 to April 2017 SRC VB Vector obtained 477 biosamples from human influenza cases including 49 biosamples from people who presumably died from influenza. Table 3 shows data on patients.

Table 1 HI test of ferret sera against highly pathogenic avian influenza A/H5 viruses circulating in Russia in 2005-2017

\begin{tabular}{|c|c|c|c|c|c|c|c|c|}
\hline \multirow[t]{2}{*}{ Virus } & \multicolumn{8}{|c|}{ Ferret serum to influenza virus } \\
\hline & $\begin{array}{l}\text { A/Common } \\
\text { gull/Chany/ } \\
2006 \\
\text { (H5N1) } \\
\text { clade } 2.2\end{array}$ & $\begin{array}{l}\text { A/Goose/ } \\
\text { Krasnoozer- } \\
\text { skoye/627/2005 } \\
\text { (H5N1) } \\
\text { clade } 2.2\end{array}$ & $\begin{array}{l}\text { A/Black- } \\
\text { Headed gull/ } \\
\text { Tyva/ } \\
115 / 2009 \\
\text { (H5N1) } \\
\text { clade } 2.3 .2\end{array}$ & $\begin{array}{l}\text { A/chicken/ } \\
\text { Prymor- } \\
\text { sky/85/2008 } \\
\text { (H5N1) clade } \\
2.3 .2\end{array}$ & $\begin{array}{l}\text { A/great } \\
\text { crested grebe/ } \\
\text { Tyva/34/2016 } \\
\text { (H5N8) clade } \\
2.3 .4 .4\end{array}$ & $\begin{array}{l}\text { A/rook/ } \\
\text { Chany/32/2015 } \\
\text { (H5N1) } \\
\text { clade 2.3.2.1.c }\end{array}$ & $\begin{array}{l}\text { A/environ- } \\
\text { ment/Kam- } \\
\text { chatka/18 } \\
\text { /2016 (H5N5) } \\
2.3 .4 .4 .\end{array}$ & $\begin{array}{l}\text { A/wigeon/ } \\
\text { Sakha/1/ } \\
2014 \\
\text { (H5N8) } \\
\text { Clade } \\
2.3 .4 .4\end{array}$ \\
\hline $\begin{array}{l}\text { A/rook/ } \\
\text { Chany/32/2015 } \\
\text { (H5N1) } \\
\text { clade 2.3.2.1.c }\end{array}$ & 320 & 320 & 640 & 640 & 640 & 640 & $<20$ & $<20$ \\
\hline $\begin{array}{l}\text { A/chicken/ } \\
\text { Sergiyev } \\
\text { Posad/38/ } \\
2017 \text { (H5N8) } \\
\text { clade } 2.3 .4 .4\end{array}$ & 1280 & $<20$ & $<20$ & $<20$ & 640 & $<20$ & 640 & 1280 \\
\hline
\end{tabular}


Table 2 Number of positive sera to highly pathogenic influenza viruses

\begin{tabular}{|c|c|c|c|c|c|c|}
\hline \multirow[t]{2}{*}{ Region } & \multirow[t]{2}{*}{ Occupation } & \multirow[t]{2}{*}{$\begin{array}{l}\text { Number of con- } \\
\text { tact persons }\end{array}$} & \multicolumn{2}{|c|}{$\begin{array}{l}\text { Number of } \mathrm{HI} \text { positive sera to } \\
\mathrm{A}(\mathrm{H} 5 \mathrm{~N} 1)\end{array}$} & \multicolumn{2}{|c|}{$\begin{array}{l}\text { Number of HI positive } \\
\text { sera to } A(H 5 N 8)\end{array}$} \\
\hline & & & $\begin{array}{l}1^{\text {st }} \text { day after } \\
\text { contact }\end{array}$ & $\begin{array}{l}21^{\text {st }} \text { day after } \\
\text { contact }\end{array}$ & $\begin{array}{l}1^{\text {st }} \text { day after } \\
\text { contact }\end{array}$ & $\begin{array}{l}21^{\text {st }} \text { day } \\
\text { after } \\
\text { contact }\end{array}$ \\
\hline Republic of Kalmykia & Backyard poultry workers & 62 & 23 & 23 & 1 & 1 \\
\hline Astrakhan region & Poultry farm workers & 56 & 0 & & 37 & 37 \\
\hline Voronezh region & Zoo workers & 12 & 0 & & 0 & \\
\hline Rostov region & Poultry farm workers & 172 & 0 & & 0 & \\
\hline Republic of Tatarstan & Poultry farm workers & 28 & 0 & & 0 & \\
\hline Nizhniy Novgorod region & Backyard poultry workers & 20 & 0 & & 15 & 16 \\
\hline Moscow region & Poultry farm workers & 362 & 4 & 4 & 6 & 6 \\
\hline Tula region & Backyard poultry workers & 10 & 0 & & 0 & \\
\hline Krasnodar Krai & Backyard poultry workers & 38 & 1 & 1 & 1 & 1 \\
\hline Total & & 760 & 28 & & 61 & \\
\hline
\end{tabular}

Table 3 Data on patients and obtained samples

\begin{tabular}{|c|c|c|c|c|c|}
\hline \multirow[t]{2}{*}{ Group } & & \multicolumn{2}{|c|}{ Fatal cases } & \multicolumn{2}{|c|}{ Severe cases } \\
\hline & & Number & $\%$ & Number & $\%$ \\
\hline \multicolumn{6}{|l|}{ Sex } \\
\hline & M & 25 & 51 & 128 & 29.9 \\
\hline & $\mathrm{F}$ & 20 & 40.8 & 280 & 65.4 \\
\hline & Unknown & 4 & 8.2 & 20 & 4.7 \\
\hline \multicolumn{6}{|c|}{ Age group } \\
\hline & $0-2$ years & 4 & 8.2 & 28 & 6.5 \\
\hline & $3-10$ years & 5 & 10.2 & 78 & 18.2 \\
\hline & $11-18$ years & 3 & 6.1 & 67 & 15.7 \\
\hline & 19-30 years & 1 & 2 & 125 & 29.2 \\
\hline & $31-45$ years & 4 & 8.2 & 69 & 16.1 \\
\hline & $46-59$ years & 9 & 18.4 & 11 & 2.6 \\
\hline & $\begin{array}{l}60 \text { years or } \\
\text { older }\end{array}$ & 20 & 40.8 & 32 & 7.5 \\
\hline & Unknown & 3 & 6.1 & 18 & 4.2 \\
\hline \multicolumn{2}{|c|}{ Pregnant women } & 0 & 0 & 166 & 38.8 \\
\hline \multicolumn{2}{|c|}{$\begin{array}{l}\text { People vaccinated against influ- } \\
\text { enza in } 2016\end{array}$} & 0 & 0 & 119 & 27.8 \\
\hline \multicolumn{2}{|l|}{ Total } & 49 & $100 \%$ & 428 & $100 \%$ \\
\hline
\end{tabular}

In six of the 477 clinical and autopsy samples we detected RNA of influenza virus $\mathrm{A}(\mathrm{H} 1 \mathrm{~N} 1)$ pdm09, in 415 - RNA of influenza virus $\mathrm{A}(\mathrm{H} 3 \mathrm{~N} 2)$ was detected, while in 56 - RNA from influenza B virus was identified.

Following the passage of autopsy and clinical material in MDCK cell cultures, we isolated 76 influenza A(H3N2) viruses, 16 influenza $B$ (Victoria) viruses and three $\mathrm{A}(\mathrm{H} 1 \mathrm{~N} 1)$ pdm09 strains. All isolated influenza A and B viruses were sensitive to antineuraminidase drugs oseltamivir and zanamivir.
Influenza $\mathrm{A}(\mathrm{H} 1 \mathrm{~N} 1)$ pdm09 viruses were subtyped in $\mathrm{HI}$ tests with reference sera to A/California/7/09, A/Florida/27/2011 and A/Mexico/254/2012 viruses. The antigenic properties of the isolated strains were similar to $\mathrm{A} /$ California/7/09 (H1N1)pdm09. Influenza B virus strains were studied in a $\mathrm{HI}$ test with reference sera to $\mathrm{B} / \mathrm{Bris}-$ bane/60/2008 (Victoria lineage) and B/Phuket/3073/2013 (Yamagata lineage). All isolated strains were similar to B/Brisbane/60/2008 (Victoria lineage). As for the $\mathrm{A}(\mathrm{H} 3 \mathrm{~N} 2)$ viruses, the majority of strains from the first passage failed to agglutinate erythrocytes of chicken, goose and guinea pig. Virus agglutination of guinea pig erythrocytes was registered after two or more passages in MDCK cell culture. After hemagglutination registration, we subtyped strains in $\mathrm{HI}$ tests with reference sera to A/ Switzerland/9715293/2013 and A/HongKong/4801/2014 viruses and diagnostic ferret sera against A/Nizhniy Novgorod/8713/2014 virus that we isolated in November 2014 [11]. HI tests were carried out in the presence of oseltamivir (20 nM) (Table 4).

It was impossible to characterize several A(H3N2) strains in $\mathrm{HI}$ tests due to a severe reduction in hemagglutinin (HA) titres in the presence of oseltamivir $(20 \mathrm{nM})$, which indicated that the hemagglutination was probably mediated by the neuraminidase (NA). Analysis of NGS data revealed the presence of polymorphism D/N/G at 151 position in the NA of these strains (Table 4). D151G and D151N substitutions can appear during cultivation in MDCK cells and result in a receptor-binding ability in NA [12].

We determined the nucleotide sequences of all genes for 31 strains, and $H A, N A$ and $N S$ gene sequences only for three strains. Figures 3 and 4 depict the phylogenetic trees for the HA and NA of influenza $\mathrm{A}(\mathrm{H} 3 \mathrm{~N} 2)$, respectively. The phylogenetic trees for the HA and NA of influenza 
Table 4 Antigenic analysis of isolated influenza A(H3N2) viruses

\begin{tabular}{|c|c|c|c|c|c|c|c|c|c|}
\hline \multirow[t]{2}{*}{ Virus } & \multirow[t]{2}{*}{$\begin{array}{l}\text { HA } \\
\text { Genetic } \\
\text { group }\end{array}$} & \multirow[t]{2}{*}{ Date collected } & \multirow{2}{*}{$\begin{array}{l}\text { Ferret anti- } \\
\text { A/Nizhniy } \\
\text { Novgorod/8713/ } \\
2014 \\
\text { (SRC Vector) }\end{array}$} & \multirow{2}{*}{$\begin{array}{l}\text { Ferret anti- A/ } \\
\text { Switzerland/ } \\
9715293 / 2013 \\
\text { (IRR, CDC) }\end{array}$} & \multirow{2}{*}{$\begin{array}{l}\text { Sheep anti- } \\
\text { A/Hong } \\
\text { Kong/4801/2014 } \\
\text { (Russian Institute } \\
\text { of Inf) }\end{array}$} & \multicolumn{3}{|c|}{$\begin{array}{l}151 \text { amino acid } \\
\text { residue in NA } \\
(\%)^{\mathrm{a}, \mathrm{b}}\end{array}$} & \multirow{2}{*}{$\begin{array}{l}\text { Reduction in HA } \\
\text { titer in the pres- } \\
\text { ence of oseltamivir } \\
(20 \mathrm{nM})\end{array}$} \\
\hline & & & & & & $\mathrm{D}$ & $\mathrm{N}$ & G & \\
\hline \multicolumn{10}{|l|}{ Reference antigen } \\
\hline $\begin{array}{l}\text { A/Nizhniy } \\
\text { Novgorod/8713/2014 }\end{array}$ & $3 c .2 a$ & 24.11 .2014 & 640 & 40 & 20 & & & & \\
\hline $\begin{array}{l}\text { A/Switzer- } \\
\text { land/9715293/2013 }\end{array}$ & $3 c .3 a$ & & 320 & 2560 & 40 & & & & \\
\hline $\begin{array}{l}\text { A/Hong } \\
\text { Kong/4801/2014 }\end{array}$ & $3 c .2 a$ & & 640 & 20 & 80 & & & & \\
\hline \multicolumn{10}{|l|}{ Test antigens } \\
\hline A/Samara/640/2016 & $3 c .2 a$ & 22.12 .2016 & & & & 73.6 & 26.3 & - & Yes \\
\hline A/Samara/711/2016 & $3 c .2 a$ & 30.12 .2016 & 160 & 40 & 20 & 98.2 & 1.8 & - & No \\
\hline A/Stavropol/3/2017 & $3 c .2 a$ & 26.12.2016 & & & & 46.6 & 53.2 & - & Yes \\
\hline A/Stavropol/4/2017 & $3 c .2 a$ & 30.01 .2017 & 1280 & 160 & 80 & 98.5 & - & 1.4 & No \\
\hline A/Voronezh/1/2017 & $3 \mathrm{c} .2 \mathrm{a}$ & 10.01 .2017 & 1280 & 160 & 80 & 99.2 & - & - & No \\
\hline A/Noyabrsk/7/2016 & $3 c .2 a$ & 28.12.2016 & 2560 & 320 & 80 & 99.6 & - & - & No \\
\hline A/Kurgan/24/2016 & $3 c .2 a$ & unknown & 2560 & 160 & 160 & 99.7 & - & - & No \\
\hline $\begin{array}{l}\text { A/Novy Uren- } \\
\text { goy/1329/2016 }\end{array}$ & $3 \mathrm{c} .2 \mathrm{a}$ & 09.12 .2016 & 640 & 80 & 80 & 99.3 & - & - & No \\
\hline A/Ekaterinburg/3/2017 & $3 \mathrm{c} .2 \mathrm{a}$ & 20.12 .2017 & & & & 35.1 & 40.1 & 24.5 & Yes \\
\hline A/Novosibirsk/01/2017 & $3 \mathrm{c} .2 \mathrm{a}$ & 19.12.2016 & & & & 79.3 & 20.6 & - & Initially low titer \\
\hline A/Novosibirsk/04/2017 & $3 \mathrm{c} .2 \mathrm{a}$ & 08.01 .2017 & & & & 71.1 & 2.3 & 26.5 & Yes \\
\hline A/Novosibirsk/2/2016 & $3 \mathrm{c} .2 \mathrm{a}$ & 31.10 .2016 & 640 & 80 & 20 & $\mathrm{ND}^{\mathrm{c}}$ & ND & ND & No \\
\hline $\begin{array}{l}\text { A/Novosibirsk/ } \\
\text { D1/2016 }\end{array}$ & $3 c .2 a$ & 30.12 .2016 & & & & 95.2 & 4.7 & - & Yes \\
\hline $\mathrm{A} / \mathrm{Omsk} / 4150 / 2016$ & $3 \mathrm{c} .2 \mathrm{a}$ & 14.12.2016 & 1280 & 160 & 80 & 97.2 & 2.6 & - & No \\
\hline $\begin{array}{l}\text { A/Krasno- } \\
\text { yarsk/22/2017 }\end{array}$ & $3 c .2 a$ & 23.01.2017 & 1280 & 160 & 40 & 99.8 & - & - & No \\
\hline $\begin{array}{l}\text { A/Krasno- } \\
\text { yarsk/1430/2017 }\end{array}$ & $3 \mathrm{c} .2 \mathrm{a}$ & 25.01.2017 & 640 & 160 & 20 & 89.2 & 10.8 & - & Yes \\
\hline $\begin{array}{l}\text { A/Krasno- } \\
\text { yarsk/1807/2017 }\end{array}$ & $3 c .2 a$ & 31.01 .2017 & & & & 99.5 & - & - & Initially low titer \\
\hline A/Surgut/73/2017 & $3 c .2 a$ & 22.12 .2016 & 640 & 80 & 20 & 99.7 & - & - & No \\
\hline A/Chita/927/2017 & $3 \mathrm{c} .2 \mathrm{a}$ & 30.12 .2016 & 640 & 160 & 40 & 99.5 & - & - & No \\
\hline
\end{tabular}

a - Frequency of NA variants determined by NGS (Illumina MiSeq)

b - Only the most prevalent nucleotide variant, deposited in GISAID, is shown

${ }^{c}$ - not determined; NGS was not performed

$\mathrm{A}(\mathrm{H} 1 \mathrm{~N} 1) \mathrm{pdm}$ and influenza $\mathrm{B}$ viruses can be viewed in the Supplementary material.

Based on the phylogenetic analysis of the full-length $\mathrm{HA}$ sequences, the $\mathrm{A}(\mathrm{H} 3 \mathrm{~N} 2)$ viruses belonged to clade 3C.2a (Fig. 3), which could be further classified into two clades: 3C.2a2 and 3C.2a3, according to classification criteria presented in [13]. For clade 3C.2a2 the combination of substitutions T131K, R142K and R261Q was seen and for clade 3C.2a3 a combination of substitutions N121K and S144K was observed.
In influenza hemagglutinin five antigenic sites are distinguished, with the most important being site $\mathrm{A}$ and site $\mathrm{B}$. It is believed that mutation in one of the sites A or B enables the virus to partially evade humoral immune response [14]. In the HA of the studied influenza $\mathrm{A}(\mathrm{H} 3 \mathrm{~N} 2)$ virus strains, we detected 19 amino acid positions with changes, in comparison with the vaccine strain A/Hong Kong/4801/2014 grown in cell culture. Fifteen of them located in the HA1 subunit and four in the HA2 subunit. All changes (K387R, D474N, G504E and G510E) in HA2 were sporadic, i.e. were detected 


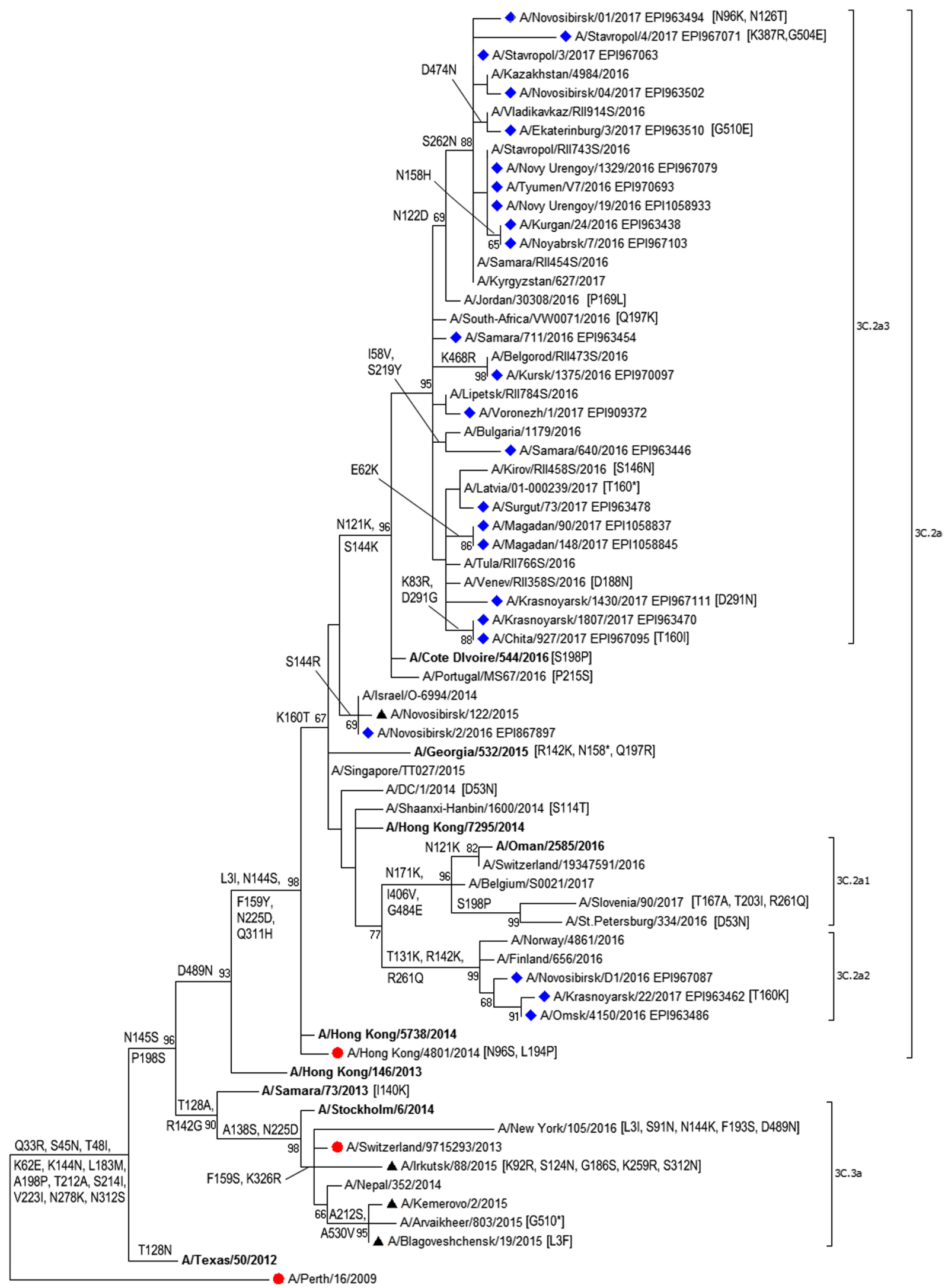

$\stackrel{5001}{0.001}$

Fig. 3 The phylogenetic tree for the HA of influenza A(H3N2) viruses isolated in this study. Positions with amino acid polymorphisms are marked by * 
Fig. 4 The phylogenetic tree for the NA of influenza A(H3N2) viruses isolated in this study. Positions with amino acid polymorphisms are marked by $*$

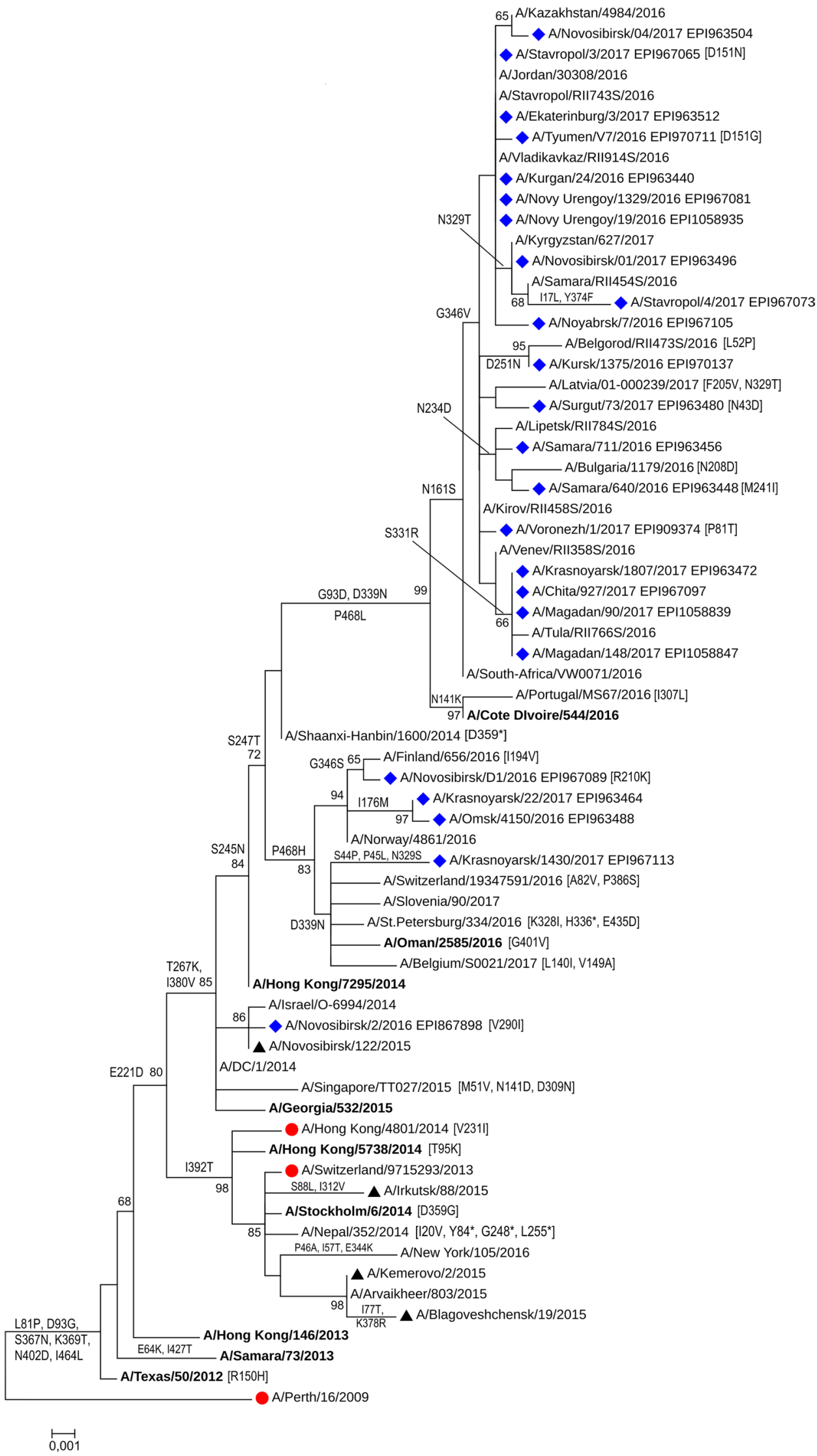


only in individual strains. Out of the 15 amino acid changes in the HA1 subunit 10 changes were located in antigenic sites [15] (mainly in site A) and consequently may cause changes in antigenic properties. Amino acid changes at positions 144,160 and 291 are believed to be the most variable, since we detected more than two amino acid variants there.

These differences in amino acid sequences imply multiple entries of influenza $\mathrm{A}(\mathrm{H} 3 \mathrm{~N} 2)$ virus into Russia. Interestingly, strains with identical amino acid changes were isolated in different and geographically distant communities.

The other $\mathrm{A}(\mathrm{H} 3 \mathrm{~N} 2)$ virus proteins sequenced revealed sporadic or less significant changes when compared to vaccine strain A/Hong Kong/4801/2014 (data not shown).

Based on phylogenetic analysis of the HA sequences, the influenza $\mathrm{B}$ (Victoria) viruses belong to the $1 \mathrm{~A}$ genetic group. The $\mathrm{A}(\mathrm{H} 1 \mathrm{~N} 1) \mathrm{pdm} 09$ viruses belong to the $6 \mathrm{~B} .1$ genetic group (Supplementary material).

\section{Discussion}

This study of 4979 sera collected in October-November 2016 from people living in regions with a high risk of emergence of viruses with pandemic potential showed the absence of antibodies to highly pathogenic A(H5N8) and $\mathrm{A}(\mathrm{H} 7 \mathrm{~N} 9)$ viruses. However, after several outbreaks of highly pathogenic influenza in the European part of Russia in November 2016 - March 2017, we detected antibodies to virus $\mathrm{A} / \mathrm{rook} / \mathrm{Chany} / 32 / 2015$ (H5N1) of clade 2.3.2.1c and virus A/chicken/Sergiyev Posad/38/2017 (H5N8) of clade 2.3.4.4 when analyzing 760 sera from people who had contact with infected or perished birds. This is the first case of detection of antibodies to highly pathogenic influenza virus in sera from a Russian population since 2008 [8]. Interestingly, we failed to detect antibodies in sera from one person at the beginning of one of the outbreaks, yet detected it in the second sera taken 21 days after the outbreak had begun. As for other people, they had antibodies at the outbreak's beginning. It is still unknown whether outbreaks were officially announced 2-3 weeks after the actual commencement of infection and the death of birds, or whether antibodies to highly pathogenic influenza were already present in human sera before the outbreak began.

The influenza epidemic season in Russia began in weeks 46-47 of 2016. We believe that concurrent circulation of seasonal and highly pathogenic influenza viruses could lead to the emergence of reassortant viruses with new antigenic and virulent properties. $\mathrm{A}(\mathrm{H} 5 \mathrm{~N} 8)$ virus outbreaks were registered in the densely populated regions of Russia (Moscow, Tula, Nizhniy Novgorod, Voronezh, Astrakhan, Rostov regions, Republic of Kalmykia and Krasnodar Krai). Therefore, in our study we gave special attention to fatal and severe influenza cases. For that purpose, we carried out whole genome sequencing of virus strains obtained from severe cases. However, no atypical virus variants were isolated from people.

In total, we isolated 95 influenza viruses from the 2016-2017 epidemic season including three A(H1N1)pdm09 strains, $76 \mathrm{~A}(\mathrm{H} 3 \mathrm{~N} 2)$ strains and 16 influenza B strains. Isolated strains were characterized according to antigenic and molecular biological properties as well as sensitivity to antineuraminidase drugs. The obtained results of our study correlate well with reports from other regions in the Northern hemisphere.

In European countries influenza activity began in the 46th week of 2016; the earliest start in an epidemic since the 2009 flu pandemic. Beginning from the 40th week of 2016, influenza A viruses were predominant accruing to $94 \%$ of all confirmed cases. The overwhelming majority of cases (99\%) accounted for were caused by the $\mathrm{A}(\mathrm{H} 3 \mathrm{~N} 2)$ subtype. A significant amount of isolated $\mathrm{A}(\mathrm{H} 3 \mathrm{~N} 2)$ viruses belonged to genetic subclade 3C.2a1 which emerged in 2015 [16].

In the 2016-2017 season genetic drift continued resulting in the formation of new genetic groups $[17,18]$ that were designated as subclades 3C.2a.2, 3C.2a.3 and 3C.2a.4 [13]. Influenza $\mathrm{A}(\mathrm{H} 3 \mathrm{~N} 2)$ virus strains isolated in this study belonged to the 3C.2a.2 and 3C.2a.3 subclades.

Among the 477 patients with severe influenza in Russia 119 people were vaccinated before the epidemic season. Influenza $\mathrm{A}(\mathrm{H} 3 \mathrm{~N} 2)$ virus antigenic drift seems to result in an inability of the vaccine strain A/HongKong/4801/2014 to provide sufficient levels of specific immunity within the vaccinated population. These data agree with the results from other countries $[19,20]$. At the same time, regardless of the insufficient efficacy of the vaccine in the 2016-2017 season in Russia, there were no confirmed fatal cases from influenza among people vaccinated in autumn 2016. All isolated strains were sensitive to antineuraminidase drugs oseltamivir and zanamivir.

Of note, in the 2016-2017 season the culturing properties of influenza $\mathrm{A}(\mathrm{H} 3 \mathrm{~N} 2)$ changed, i.e. this virus grew significantly worse in MDCK cell culture when compared to the vaccine strain. In addition strains of the first passage frequently failed to agglutinate erythrocytes of chicken, goose and guinea pig. Virus agglutination of guinea pig erythrocytes was registered only after two or more passages in MDCK cell culture. Since the stains isolated in the current study did not belong to 3C.2a1 genetic group, which decreases hemagglutination activity [21,22], it is possible that the absence of hemagglutination can be considered as a common property of virus strains in the 2016-2017 season.

\section{Conclusion}

Just before the epidemic season in Russia 55.9 million people (38.2\%) were vaccinated. The percentage of the population with protective antibody titers against influenza $\mathrm{A}$ and 
B virus vaccine strains was $25-50 \%$ depending on region (October-November 2016).

Our analysis of 4979 blood sera samples (collected before the 2016-2017 epidemic season) from people living in regions with an increased risk of emergence of influenza viruses with pandemic potential, failed to detect antibodies to highly pathogenic influenza $\mathrm{A}(\mathrm{H} 5 \mathrm{~N} 8)$ and $\mathrm{A}(\mathrm{H} 7 \mathrm{~N} 9)$.

Between November 2016 and March 2017 outbreaks of highly pathogenic influenza among wild birds and poultry were registered in Russia. There was no clinical evidence of human disease; however, analysis of sera from people who had contact with infected or perished birds demonstrated the presence of antibodies to A/rook/Chany/32/2015 (H5N1) of clade 2.3.2.1 $\mathrm{c}$ in 28 people and antibodies to $\mathrm{A} /$ chicken/Sergiyev Posad/38/2017 (H5N8) of clade 2.3.4.4 in 61 people.

The 2016-2017 influenza epidemic season in Russia began in the 46th-47th weeks of 2016 with predominant circulation of influenza $\mathrm{A}(\mathrm{H} 3 \mathrm{~N} 2)$ virus. Up to the 8 th week of 2017, we isolated strains belonging mainly to the 3C.2a genetic group (subclades 3C.2a.2 and 3C.2a.3) from clinical and autopsy material. The majority of strains from the first passage failed to agglutinate erythrocytes of chicken, goose and guinea pig. From the 8th week to 12th week of 2017 severe influenza cases were frequently caused by influenza $\mathrm{B}$ (Victoria) viruses belonging to the $1 \mathrm{~A}$ genetic group with antigenic properties similar to B/Brisbane/60/2008. During the whole epidemic season, we confirmed six severe influenza cases caused by $\mathrm{A}(\mathrm{H} 1 \mathrm{~N} 1)$ pdm09 virus; all isolated strains were similar to the A/California/7/2009 strains. All isolated influenza A and B virus strains in the 2016-2017 epidemic season were sensitive to oseltamivir and zanamivir.

Acknowledgements This work was supported by State Assignment no. 1/16 (SRC VB "Vector").

\section{Compliance with ethical standards}

Conflict of interest All authors declare that they have no conflict of interest.

\section{References}

1. Paules C, Subbarao K (2017) Influenza. Lancet 390(10095):697_ 708. https://doi.org/10.1016/S0140-6736(17)30129-0

2. WHO (2017) FluNet. http://www.who.int/influenza/ gisrs_laboratory/flunet/en//.

3. Rospotrebnarzor (2017) [On the results of influenza and ARD epidemic season of 2016-2017].

4. Ilyicheva T, Durymanov A, Susloparov I, Kolosova N, Goncharova N, Svyatchenko S, Petrova O, Bondar A, Mikheev V, Ryzhikov A (2016) Fatal cases of seasonal influenza in Russia in 2015-2016. PLoS One 11(10):e0165332. https://doi.org/10.1371/ journal.pone.0165332

5. Marchenko VY, Susloparov IM, Sapronova NY, Goncharova NI, Kolosova NP, Evseenko VA, Svyatchenko SV, P'yankova OG,
Ziatdinov VB, Limanskaya OS, Dzhambinov SD, Shendo GL, Mikheev VN, Maksyutov RA, Ryzhikov AB (2017) Characterization of avian influenza H5N8 virus strains that caused the outbreaks in the Russian Federation in 2016-2017. Probl Part Danger Infections. https://doi.org/10.21055/0370-1069-2017-3-68-74

6. WHO (2011) World Health Organization Surveillance Network: manual for the laboratory diagnosis and virological surveillance of influenza. World Health Organization, Geneva

7. Marchenko VY, Susloparov IM, Komissarov AB, Fadeev A, Goncharova NI, Shipovalov AV, Svyatchenko SV, Durymanov AG, Ilyicheva TN, Salchak LK, Svintitskaya EP, Mikheev VN, Ryzhikov AB (2017) Reintroduction of highly pathogenic avian influenza A/H5N8 virus of clade 2.3.4.4. in Russia. Arch Virol 162(5):1381-1385. https://doi.org/10.1007/s00705-017-3246-z

8. Ilyicheva T, Sobolev I, Susloparov I, Kurskaya O, Durymanov A, Sharshov K, Shestopalov A (2013) Monitoring of influenza viruses in Western Siberia in 2008-2012. Infect Genet Evol 20:117-187. https://doi.org/10.1016/j.meegid.2013.08.025

9. Katz J, Hancock K, Veguilla V, Zhong W, XH L, Sun H, Butler E, Dong L, Liu F, Li ZN, DeVos J, Gargiullo P, Cox N (2009) Serum cross-reactive antibody response to a novel influenza A (H1N1) virus after vaccination with seasonal influenza vaccine. Morb Mortal Wkly Rep 58(19):521-524

10. WHO (2007) Standard operating procedure WHO—025: fluorometric neuraminidase inhibition assay. WHO, Geneva

11. Svyatchenko SV, Durymanov AG, Susloparov IM, Kolosova NP, Goncharova NI, Mikheev VN, Ryzhikov AB, Ilyicheva TN (2016) Severe and fatal influenza cases in Russia in 2014-2015. Online J Biol Sci 16(4):184-192. https://doi.org/10.3844/ojbsc i.2016.184.192

12. Chambers BC, Li Y, Hodink RL, Hensley SE (2014) Recent H3N2 influenza virus clinical isolates rapidly acquire hemagglutinin or neuraminidase mutations when propagated for antigenic analyses. J Virol 88(18):10986-10989. https://doi.org/10.1128/JVI.01077 $-14$

13. Yang J-R, Hsu S-Z, Kuo C-Y, Huang H-Y, Huang T-Y, Wang H-C, Liu M-T (2018) An epidemic surge of influenza A(H3N2) virus at the end of the 2016-2017 season in Taiwan with an increased viral genetic heterogeneity. J Clin Virol 99-100:15-21. https:// doi.org/10.1016/j.jcv.2017.12.012

14. Kratsch C, Klingen TR, Mumken L, Steinbruck L, McHardy AC (2016) Determination of antigenicity-altering patches on the major surface protein of human influenza A/H3N2 viruses. Virus Evol 2(1):vv025 (10.1093/ve/vev025)

15. Stray SJ, Pittman LB (2012) Subtype- and antigenic sitespecific differences in biophysical influences on evolution of influenza virus hemagglutinin. Virol J 9:91. https://doi. org/10.1186/1743-422x-9-91

16. Korsun N, Angelova S, Trifonova I, Tzotcheva I, Mileva S, Voleva S, Georgieva I, Perenovska P (2018) Predominance of influenza A(H3N2) viruses during the $2016 / 2017$ season in Bulgaria. J Med Microbiol 67(2):228-239. https://doi.org/10.1099/jmm.0.000668

17. Glatman-Freedman A, Drori Y, Beni SA, Friedman N, Pando R, Sefty H, Tal I, McCauley J, Rahav G, Keller N, Shohat T, Mendelson E, Hindiyeh M, Mandelboim M (2017) Genetic divergence of Influenza $\mathrm{A}(\mathrm{H} 3 \mathrm{~N} 2)$ amino acid substitutions mark the beginning of the 2016-2017 winter season in Israel. J Clin Virol 93:71-75. https://doi.org/10.1016/j.jcv.2017.05.020

18. Trebbien R, Fischer TK, Krause TG, Nielsen L, Nielsen XC, Weinreich LS, Lis-Tønder J, Skov MN, Christiansen CB, Emborg H-D (2017) Changes in genetically drifted H3N2 influenza A viruses and vaccine effectiveness in adults 65 years and older during the 2016/17 season in Denmark. J Clin Virol. https://doi. org/10.1016/j.jcv.2017.06.007

19. Skowronski DM, Chambers C, Sabaiduc S, Dickinson JA, Winter A-L, De Serres G, Drews SJ, Jassem A, Gubbay JB, Charest H, 
Balshaw R, Bastien N, Li Y, Krajden M (2017) Interim estimates of 2016/17 vaccine effectiveness against influenza A(H3N2), Canada, January 2017. Eurosurveillance 22(6):30460. https:// doi.org/10.2807/1560-7917.ES.2017.22.6.30460

20. Flannery B, Chung JR, Thaker SN, Monto AS, Martin ET, Belongia EA, McLean HQ, Gaglani M, Murthy K, Zimmerman RK, Nowal MP, Jackson MJ, Jackson LA, Foust A, Sessions W, Berman L, Spencer S (2017) Fry AM (2017) Interim Estimates of 2016-17 Seasonal Influenza Vaccine Effectiveness-United States. Morb Mortal Wkly Rep 66(6):167-171. https://doi. org/10.15585/mmwr.mm6606a3

21. CDC (2018) Weekly U.S. Influenza Surveillance Report. https:// www.cdc.gov/flu/weekly/

22. Report prepared for the WHO annual consultation on the composition of influenza vaccine for the Northern Hemisphere 2017-2018 (2017). The Crick Worldwide Influenza Centre, London 